\title{
SWOT Analysis of Private College Library and Its Development Strategy
}

\author{
Xiaofang Qiu \\ Fuzhou University of International Studies and Trade \\ Fuzhou, China
}

\begin{abstract}
The private higher education of China booms with the development of higher education and promotes social and economic development. On this occasion, libraries in private colleges face new opportunities and have problems in the development. In order to seize the opportunities and meet the challenges, libraries in private colleges should use SWOT analytical method in management to analyze. This paper roundly analyzes the current situation and prospect of libraries in private colleges through "SWOT" analytical method and carefully analyzes external opportunities and threats, strengths and weaknesses of them, taking different strategies to seek better survival and development.
\end{abstract}

Keywords—private colleges; libraries; SWOT analysis; strategy

\section{INTRODUCTION}

In recent years, private colleges in our country expand scales and develop fast to meet people's diversified requirements for higher education and train useful talents. They face new opportunities as well as have problems in development. In order to seize the opportunities and meet the challenges, libraries in private colleges should use SWOT analytical method in management to analyze. SWOT analytical method was raised by a management professor of University of San Francisco in the early 1980s. It can objectively and correctly analyze and research the current state of a unit. On one hand, analyze internal environment and find Strengths and Weaknesses; on the other hand, analyze external environment and find Opportunities and Threats. Formulate appropriate development strategies through analysis of the four elements.

\section{SWOT ANALYSIS OF LIBRARY IN PRIVATE COLLEGES}

\section{A. Analyze Internal Strengths of Library in Private Colleges}

Strengths refer to the elements that an organization has to do better than competitors. Private colleges have strengths so that they can survive and develop.

1) The library work based on market demands: The schoolrunning mechanism of private colleges is flexible. Private colleges can break through the limitation of traditional schoolrunning idea and reform teaching with the strengths like independent management and autonomy of school-running. They can timely adjust the talent training objectives and teaching contents, build school-running, course and talent training models suitable for the market needs. Library in private colleges can make use of the strengths and adjust library work according to changes and requirements of the market, laying a solid foundation for the cultivation of talents urgently required by the country and the society. The marketoriented school-running model makes library of private colleges have competitive advantages.

2) Flexible operation and management mechanism of library: Private colleges have established flexible management system, employment system and distribution system as well as assessment, reward and punishment systems since the foundation of library. They relate job performance to rewards and punishments through assessment of library teachers. Therefore, private colleges have the strengths of flexible and efficient management system of libraries.

3) Easier to form features of libraries: Libraries of private colleges can determine the features of libraries according to teachers, school fund, cultural and economic development in the place where the school locates. The features of libraries embody school-running property of colleges, social service direction and local industry characteristics. Meanwhile, it reflects the target location and professional construction layout of libraries in colleges. School-running features are not overall advantage but local advantage of libraries in private colleges.

\section{B. Analyze Internal Weakness of Library in Private Colleges.}

Weaknesses refer to the deficiencies of social organization by comparison with its competitors.

1) The integral development of teaching body in library is unstable and the quality of library teachers is low: At present, the development of library in private colleges is unstable, especially the teaching body of libraries. It is the weakness of private colleges. Library teachers in private colleges are not well-paid, so that many resign and the teaching body of library is unstable. Libraries of private colleges fail to have a large number of library teachers with good stability and high quality.

2) Library of private colleges has capital shortage: Most educational funds of private colleges are donation of enterprises or individuals. The rest of it comes from tuition fee. Because of lacking mental preparation for the large investment, most private colleges lack funds and fail to meet the requirements of talent training objectives. The number of library facilities is inadequate. The library equipment is backward. The books and reference materials are short. And the space in library is narrow. In order to develop further, private colleges require lots of funds to purchase books, library 
equipment and build learning place in the library and continuously transform and update hardware and software of libraries. Maybe the government will give some supports but it is not a permanent solution. Therefore, capital shortage is a great threat for library in private colleges.

\section{Analyze External opportunities of Library in Private Colleges}

Opportunities refer to the favorable influences on the survival and development of an organization because of the changes of external environment.

1) The policies of the Ministry of Education provide space for the development of college libraries: The national policies provide broad space for the development of private higher education. The introduction of Non-governmental Education Promotion Law affirms the position of private education legally and it is also the primary basis for private education to run school by law. This law regulates the behaviors of private colleges providing college degree or above in running school, safeguards the legal rights and interests of founder, teachers and students of private colleges and guides the healthy development of private colleges. Therefore, it makes for the steady development of libraries in private colleges.

2) The market greatly needs high quality skilled talents: Traditional colleges mainly train academic, research oriented and design talents. They fail to keep pace with the times in library management. However, at present, many large and medium-size enterprises urgently need skilled talents. Because the society is short of skilled talents especially high quality skilled talents, private colleges training high quality skilled talents are popular. It is a Heaven-sent chance for library in private colleges to distinguish itself. Such a chance must not be missed.

\section{Analyze External Threats of Private Colleges}

Threats refer to the unfavorable influences on organizations because of the changes of external environment.

1) Whether the library in private colleges is sound: Influenced by the past policies and some old concepts, some parents think private colleges only provide low level and informal education. The misunderstanding is a great threat for the survival and development of private colleges. They doubt the diploma issued by private colleges and the education quality of private colleges. Meanwhile, they doubt whether the library in private colleges is sound and becomes the second classroom of students and provides a broad space for students to learn. It has unfavorable influences on the reputation of library in private colleges.

2) The library in private colleges faces fierce competition: Under the condition of market economy, the social resources are inclined to gather in libraries of prestigious key universities with strong overall strength, so these libraries become increasingly strong. Because they in prestigious universities, it is easier for them to attract large amounts of excellent resources and obtain achievements in library. By comparison, obviously, the overall competitiveness of libraries in private colleges is poor, so that they face greater threats in the fierce competition.

\section{DEVELOPMENT STRATEGIES FOR LIBRARIES IN PRIVATE COLLEGES}

According to the above-mentioned SWOT analysis of internal and external environments, with the vigorous development of Chinese higher education, libraries in private colleges should take the following measures, in order to adopt others' good points and avoid its shortcomings, draw on advantages and avoid disadvantages and seize the opportunities to develop.

\section{A. Define the Positioning of Library Scientifically, Correctly and Elaborately}

In order to become irreplaceable, colleges require a definite positioning. The more distinctive of positioning, the more prominent the school-running characteristics will be. The positioning of college library is the same. The positioning of school library needs to handle the relationship between universality and individuality. "Universality" means observing the law of education. "Individuality" means libraries with different training objectives, types and models have different development laws. Therefore, under the guidance of law of education and correct school-running direction, it is necessary to avoid the same school-running positioning, reflecting the difference and characteristics of library positioning.

\section{B. Improve Management and Quality of Libraries in Private Colleges}

Libraries in private colleges should make good use of the autonomous right in management system, employment system and distribution system as well as more development space to exploit the advantages to the full. At present, the teaching body of libraries in private colleges is unstable with low quality. The stability and quality of library teachers is the core of success of private colleges. College libraries should adhere to "peopleoriented" management idea and create environment favorable for library teachers' growth, work and mentality and retain them with respect.

\section{Expand Financing Channels to Guarantee A Stable Capital Source for Libraries}

Problems in capital shortage and financing channels must be solved to ensure the sustainable development of libraries in private colleges. Firstly, because private colleges do not seek profits, the government has compelling obligation in financial assistance. The government can properly give financial supports or take measures to support the long-term development of libraries in private colleges. Secondly, libraries in private colleges can obtain the support of enterprises through flexible mechanism. Lastly, establish donation system and formulate preferential policies to encourage the donation to education. 


\section{Integrity Is Important to Create A Good Reputation of}

\section{Libraries}

Some parents are dissatisfied with libraries in private colleges. The creation of brand and good social reputation of private colleges bases on integrity. The Enforcement Regulation for Non-governmental Education Promotion Law expressly stipulates that the enrollment propaganda of private colleges must be correct, true, legal, normative and detailed and responsible. Libraries of private colleges can create an atmosphere of integrity management, responsible for students, parents and the society.

\section{E. The Government and the Society Support the Development} of Libraries in Private Colleges

The government and the society should take a clear-cut stand to support the development of private colleges and implement, namely create a development environment with fair competition, innovation encouragement without discrimination for them. It provides a great chance for the development of libraries in private colleges. For example, timely standardize, pay attention to and support the sound management system and reasonable development system of libraries. Therefore, it can guarantee the enthusiasm and creativity of library teachers in private colleges.

\section{CONCLUSION}

In conclusion, libraries in private colleges should formulate correct development strategies and the government departments should take measures to obtain the long-term and healthy development of libraries in private colleges, in order to train more useful high quality skilled talents for the society.

\section{REFERENCES}

[1] Wang Ying. Research on Management Mechanism of Operation and Construction of College Library Based on KANO Model and SWOT Analytical Method [J], Sci-Tech Information Development and Economy, 2015 (08): 33-36

[2] Deng Xiuxia. Management Innovation of Library Based on Triangle Theory [J], Beijing: Tsinghua University Press, 2016 (08): 219-222

[3] Zhu Ming. Research Review of Effectiveness of Management System in Libraries of Other Countries [J], Library and Information Service, 2015 (09): 142-147 